\title{
Ankle-Brachial Index as a Predictor of Significant Coronary Artery Disease in Patients Undergoing Coronary Angiography
}

\author{
Marcelo Sabedotti ${ }^{1}$, Rogerio Sarmento-Leite ${ }^{2}$, Alexandre Schaan de Quadros ${ }^{2}$
}

\begin{abstract}
Background: The ankle-brachial index is a simple and effective tool for diagnosing peripheral artery disease, but has not been validated for the diagnosis of coronary artery disease. The aim of this study was to evaluate the ability of the ankle-brachial index to predict coronary artery disease in patients undergoing coronary angiography. Methods: Patients with clinical suspicion of coronary artery disease and indication for coronary angiography were prospectively evaluated. Significant coronary artery disease was defined as the presence of stenosis $>70 \%$ of at least one major epicardial coronary artery or any of their major branches. A ROC curve was developed to define the ankle-brachial index cutoff that best predicts coronary artery disease. Results: A total of 312 patients were evaluated: mean age was $57 \pm 11$ years and $50 \%$ were male. One hundred and sixteen (37.2\%) patients had significant coronary disease. Ankle-brachial index measurement in these patients was significantly lower than in those without coronary artery disease $(0.88 \pm 0.14$ vs. $0.96 \pm 0.87$; $p<0.01)$. Ankle-brachial index $<0.87$ showed a sensitivity of $31 \%$, specificity of $95.4 \%$, positive predictive value of $75.9 \%$ and negative predictive value of $71.6 \%$. The area under the ROC curve was 0.73 (95\% confidence interval of 0.67-0.79). Conclusions: Ankle-brachial index $<0.87$ had a high specificity to predict significant coronary disease. Considering its low cost and ease of use, measurement of ankle-brachial index may be incorporated to daily clinical practice to help diagnose significant coronary artery disease.
\end{abstract}

DESCRIPTORS: Atherosclerosis. Cardiovascular diseases. Ankle brachial index. Risk factors. Coronary angiography.
RESUMO

\section{Índice Tornozelo-Braquial como Preditor de Doença Coronariana Significativa em Pacientes Submetidos à Angiografia Coronária}

Introdução: O índice tornozelo-braquial é uma ferramenta simples e efetiva para diagnosticar doença arterial periférica, porém não foi ainda validado para o diagnóstico de doença arterial coronariana. O objetivo deste estudo foi avaliar o desempenho do índice tornozelo-braquial em predizer doença arterial coronariana em pacientes submetidos à angiografia coronária. Métodos: Pacientes com suspeita clínica de doença arterial coronariana e indicação de angiografia coronária foram avaliados prospectivamente. Doença arterial coronariana significativa foi definida como estenose $\geq 70 \%$ em pelo menos uma coronária epicárdica maior ou ramo principal. Uma curva ROC foi construída para definir o ponto de corte do índice tornozelo-braquial que melhor predizia doença arterial coronariana. Resultados: Foram estudados 312 pacientes, cuja média de idades foi $57 \pm 11$ anos e $50 \%$ eram do sexo masculino. Tinham doença coronariana significativa 116 pacientes $(37,2 \%)$. A medida do índice tornozelo-braquial nestes pacientes foi significativamente menor do que naqueles sem doença arterial coronariana $(0,88 \pm 0,14$ vs. $0,96 \pm 0,87$ $p<0,01)$. Índice tornozelo-braquial $\leq 0,87$ mostrou sensibilidade de $31 \%$, especificidade de $95,4 \%$, valor preditivo positivo de $75,9 \%$ e valor preditivo negativo de $71,6 \%$. A área da curva ROC foi 0,73 (intervalo de confiança de $95 \%$ 0,67-0,79). Conclusões: Índice tornozelo-braquial $\leq 0,87$ teve alta especificidade para predizer doença arterial coronariana significativa. Considerando o baixo custo e a fácil utilização, a medida do índice tornozelo-braquial pode ser adicionada na prática clínica para auxiliar no diagnóstico de doença arterial coronariana significativa.

DESCRITORES: Aterosclerose. Doenças cardiovasculares. Índice tornozelo-braço. Fatores de risco. Angiografia coronária.

\footnotetext{
${ }^{1}$ Universidade de Caxias do Sul, Caxias do Sul, RS, Brazil.

${ }^{2}$ Instituto de Cardiologia do Rio Grande do Sul, Porto Alegre, RS, Brazil.
}

\footnotetext{
Correspondence to: Marcelo Sabedotti. Rua Francisco Getúlio Vargas, 1.130 - Petrópolis - CEP: 95070-560 - Caxias do Sul, RS, Brazil

E-mail: msabedotti@me.com
} 
A therosclerosis is a systemic disease, which is not restricted only to a vascular territory. Coronary artery disease (CAD) and peripheral arterial disease (PAD) are commonly found in the same patient, ${ }^{1}$ and this condition is associated with high risk of cardiovascular events. ${ }^{2,3}$

In clinical practice, preventive actions are recommended in cardiology, ${ }^{4-7}$ and risk stratification and early treatment are very important strategies to reduce cardiovascular disease and its consequences. ${ }^{8}$

The ankle-brachial index $(\mathrm{ABI})$ is a simple and effective tool for PAD screening. ${ }^{9} \mathrm{ABI}<0.90$ is considered as altered, and has a $95 \%$ sensitivity for predicting peripheral vascular disease with significant stenosis on angiography. ${ }^{10}$ In addition, $\mathrm{ABI}<0.90$ is associated with a worse cardiovascular prognosis and increased all-cause mortality. ${ }^{11-15}$ Although $A B I$ is useful for detecting PAD, its validity in predicting CAD is not well established.

This study aimed to evaluate the performance of $A B I$ as a predictor of $C A D$ in patients undergoing coronary angiography.

\section{METHODS}

This protocol was approved by the ethics committee and met all clinical research criteria in Brazil. All patients received information about the study and signed an informed consent.

This was a cross-sectional study, for which consecutive patients referred for coronary angiography for suspected CAD were selected. Patients with previous coronary angiography, $\mathrm{ABI}>1.0$, severe valve disease, acute coronary syndrome, and those who did not agree to sign the informed consent were excluded from this analysis.

\section{Clinical evaluation and measurement of ankle- brachial index}

Patients were clinically evaluated before their coronary angiography through physical examination and medical history; information on the classic risk factors for ischemic heart disease was collected.

$\mathrm{ABI}$ was measured as recommended by current guidelines. ${ }^{9}$ Systolic pressure was measured in upper and lower limbs with a portable vascular Doppler device DV610 ${ }^{\circledast}$ (Medmega - Franca, São Paulo, Brazil). In the $A B I$ calculation, the ratio between anterior and/ or posterior tibial artery pressure (the highest value was considered) and brachial systolic pressure was used. In the case of differing values between left and right side, the lowest value was used in this analysis.

\section{Coronary angiography}

Quantitative coronary angiography was the parameter used for diagnosis of coronary stenosis. After clinical evaluation, the patients underwent coronary angiography (Judkins technique) through the femoral artery. Quantitative coronary angiography was performed by an independent investigator. Coronary disease was considered significant in the presence of a stenosis $\geq 70 \%$ in at least one coronary segment.

\section{Statistical analysis}

Quantitative variables were expressed as means \pm standard deviations and compared using Student's $t$-test. Qualitative variables were presented as absolute numbers and percentages and compared using the chi-squared test or Fisher's exact test, as appropriate. The determination of the cutoff for $\mathrm{ABI}$ was performed by receiver operating characteristic (ROC) curve. This statistical analysis was performed with SPSS version 15.0 (Chicago, Illinois, United States).

\section{RESULTS}

From March to December of 2013, 312 patients were included in this study. The mean age was $57 \pm$ 11 years, $50 \%$ were male, and $24.4 \%$ were diabetic (Table 1). One hundred and sixteen patients $(37.2 \%)$ were diagnosed with significant CAD. In these individuals, $A B I$ was significantly lower than in those patients without significant CAD $(0.88 \pm 0.14$ vs. $0.96 \pm 0.87$; $p<0.01)$.

The specificity of $A B I$ for predicting significant CAD in patients with $\mathrm{ABI} \leq 0.87$ was $95.4 \%(95 \%$ confidence interval $-95 \% \mathrm{Cl}, 91.7-97.7)$, with a sensitivity of $31 \%(95 \% \mathrm{Cl}, 23.1-39.9)$ (Figure); the positive predictive value was $75.9 \%$ and the negative predictive value was $71.6 \%$.

TABLE 1

Patients' characteristics and risk factors for coronary arterial disease (CAD)

\begin{tabular}{lccc}
\hline & $\begin{array}{c}\text { Without } \\
\text { significant } \\
\text { Characteristics }\end{array}$ & $\begin{array}{c}\text { With } \\
\text { significant } \\
\text { CAD }\end{array}$ & \\
\hline Age, years & $56 \pm 11$ & $61 \pm 11$ & $<0.01$ \\
(n= 116) & p-value \\
Male gender, n (\%) & $76(38.8)$ & $80(69.0)$ & $<0.01$ \\
Risk factors for CAD, & & & \\
n (\%) & $141(71.9)$ & $99(85.3)$ & $<0.01$ \\
Hypertension & $29(14.8)$ & $47(40.5)$ & $<0.01$ \\
Diabetes & $73(37.2)$ & $78(67.2)$ & $<0.01$ \\
Hyperlipidemia & $69(35.2)$ & $74(63.8)$ & $<0.01$ \\
Current smoking & $78(39.8)$ & $50(43.1)$ & 0.63 \\
Family history of CAD & $13(6.6)$ & $44(37.9)$ & $<0.01$ \\
ABI $\leq 0.87, \mathrm{n}(\%)$ & & & \\
\hline
\end{tabular}

*Presence of stenosis $\geq 70 \%$ in a coronary artery or main coronary branch. $\mathrm{ABI}$ : ankle-brachial index. 
The probability of a significant coronary lesion presentation for patients undergoing coronary angiography can also be predicted by $\mathrm{ABI}$. With an $\mathrm{ABI} \leq 0.87$, the probability of significant CAD was $77.2 \%$. As shown in Table 2, it was observed that the lower the $\mathrm{ABI}$, the greater the likelihood of a significant CAD.

A model was created to predict the occurrence of significant $C A D$ associated with risk factors for this disease with $\mathrm{ABI}$. For example, patients with $\mathrm{ABI} \leq 0.87$ and four risk factors had a $90.5 \%$ probability of significant CAD (Table 3).

\section{DISCUSSION}

This study evaluated the sensitivity and specificity of $\mathrm{ABI}$ for predicting significant $\mathrm{CAD}$ in patients undergoing coronary angiography. CAD and PAD are two major problems of modern medicine, due to the mortality, reduced life expectancy, and social and economic impacts associated with these conditions. ${ }^{16}$

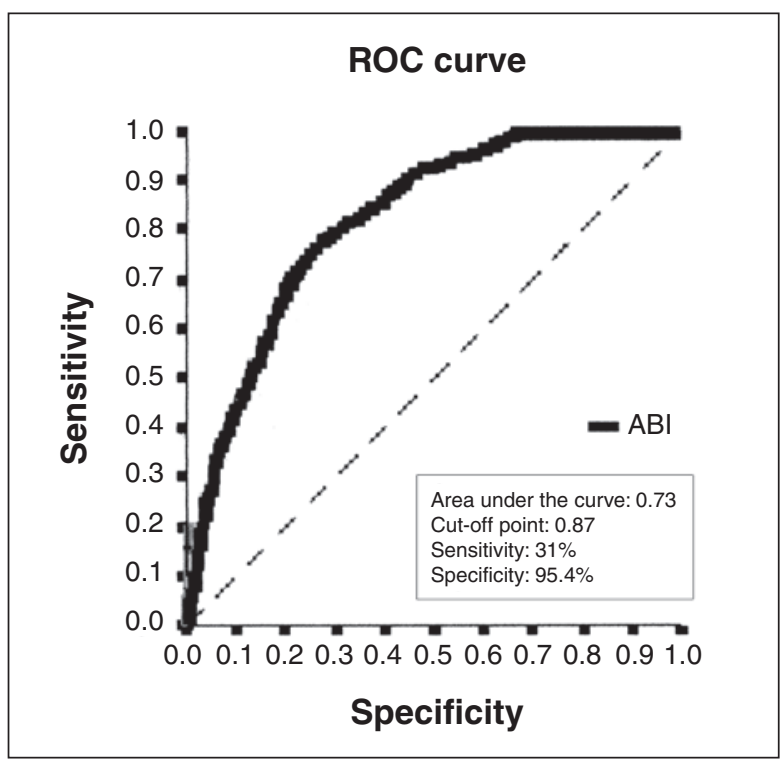

Figure - Receiver operating characteristic curve of ankle-brachial index (ABI) determination, related to the presence of stenosis $\geq 70 \%$ in a coronary artery or in a main coronary branch in angiography.
CAD may be present in $58 \%$ of patients with PAD, ${ }^{17}$ and such an association is related to a worse prognosis. The diagnosis and early treatment are critical in order to minimize cardiovascular events.

$\mathrm{ABI}$ is a useful tool for diagnosing PAD, and $\mathrm{ABI}<0.5$ is associated with claudication when walking $100 \mathrm{~m} .{ }^{18}$ Lee et al. ${ }^{19}$ have previously proved an association between low $\mathrm{ABI}$ with high risk of cardiovascular and cerebrovascular events and death. Patients with $\mathrm{ABI}<0.90$ present an increased risk of cardiovascular events, and low $\mathrm{ABI}$ was an independent predictor of risk of fatal myocardial infarction, even after adjustment for traditional risk factors for CAD. Additionally, ABI increased significantly $(p<0.01)$ the predictive value for fatal myocardial infarction, when compared with a model considering only risk factors for CAD. However, $\mathrm{ABI}$ is not fully validated for detecting CAD. The present study demonstrated the usefulness of this index in predicting significant coronary lesions.

When used as a single diagnostic method, $\mathrm{ABI}$ does not have good sensitivity for predicting CAD. However, when indexes $\leq 0.87$ were considered, the specificity was $95.4 \%$. Otah et al. ${ }^{20}$ demonstrated that three-vessel arterial disease or left main coronary artery disease can be predicted by the ITB, with sensitivity and specificity of $85 \%$ and $77 \%$, respectively. In the present study, the sensitivity was low, but with higher specificity. Probably the main reason for this finding was the criterion used for CAD. In the present study, only cases of CAD with $\geq 70 \%$ stenosis were considered as significant, while Otah et al. ${ }^{20}$ considered all coronary injuries that were diagnosed. Perhaps these different criteria have contributed to these differences in results.

Although $\mathrm{ABI}$ per se does not have a high sensitivity to detect $C A D$, with an index $\leq 0.87$ the probability of the patient having a significant CAD is estimated in $77.2 \%$. When associating $\mathrm{ABI}$ with risk factors for CAD, the probability of lesions $\geq 70 \%$ in coronary angiography increases. Considering patients with four or more risk factors and an $\mathrm{ABI} \leq 0.87$, approximately $90 \%$ have a significant CAD. This suggests that $\mathrm{ABI}$ is most useful when combined with clinical assessment data. Thus, the combination of these elements allows fora reasonable probability of predicting significant CAD.

TABLE 2

Probability of significant coronary artery disease (CAD) in relation to the ankle-brachial index (ABI)

\begin{tabular}{lccc}
\hline ABI & Without significant CAD $(\mathbf{n = 1 9 6 )}$ & Chance of significant CAD* (\%) & Odds Ratio \\
\hline$\leq 0.87$ & 13 & 77.2 & 5.66 \\
$0.88-0.92$ & 32 & 48.4 & 1.58 \\
$0.93-0.96$ & 10 & 33.3 & 0.84 \\
$\leq 0.97$ & 141 & 20.9 & 0.44 \\
\hline
\end{tabular}

*Presence of stenosis $\geq 70 \%$ in a coronary or main coronary branch. 
TABLE 3

Probability of significant coronary artery disease (CAD) in relation to ankle-brachial index (ABI) and coronary risk factors*

\begin{tabular}{lcccc}
\hline $\begin{array}{l}\text { Number } \\
\text { of risk } \\
\text { factors }\end{array}$ & \multicolumn{4}{c}{$\mathbf{A B I}$} \\
\cline { 2 - 5 } & $\mathbf{0 . 8 7}$ & $\mathbf{0 . 8 8 - 0 . 9 2}$ & $\mathbf{0 . 9 3 - 0 . 9 6}$ & $\geq \mathbf{0 . 9 7}$ \\
\hline$\leq 1$ & $50 \%$ & $0 \%$ & $0 \%$ & $3.6 \%$ \\
& $(\mathrm{n}=4)$ & $(\mathrm{n}=12)$ & $(\mathrm{n}=0)$ & $(\mathrm{n}=55)$ \\
$2-3$ & $70.6 \%$ & $47.1 \%$ & $36.4 \%$ & $22.2 \%$ \\
& $(\mathrm{n}=34)$ & $(\mathrm{n}=34)$ & $(\mathrm{n}=11)$ & $(\mathrm{n}=99)$ \\
$\geq 4$ & $90.5 \%$ & $87.5 \%$ & $25 \%$ & $56.5 \%$ \\
& $(\mathrm{n}=21)$ & $(\mathrm{n}=16)$ & $(\mathrm{n}=4)$ & $(\mathrm{n}=22)$ \\
\hline
\end{tabular}

*Presence of stenosis $\geq 70 \%$ in a coronary artery or main coronary branch; coronary risk factors were hypertension, current smoking, dyslipidemia, diabetes mellitus, and family history of coronary artery disease.

\section{Study limitations}

The present study had some limitations that should be mentioned. This was a cross-sectional study with a small number of patients. In addition, most patients had established risk factors for ischemic heart disease and were referred for coronary angiography for suspected CAD. Perhaps this sample represents a high-risk population with a high prevalence of CAD, and may have overestimated the predictive values of $\mathrm{ABI}$.

\section{CONCLUSIONS}

$\mathrm{ABI}$ values $\leq 0.87$ showed high specificity to predict significant coronary artery disease. Considering its low cost and ease of use, $\mathrm{ABI}$ should be added to the physical examination, as a useful method to stratify the risk of coronary artery disease.

\section{CONFLICT OF INTERESTS}

The authors declare no conflicts of interest.

\section{FUNDING SOURCE}

\section{None.}

\section{REFERENCES}

1. Ness J, Aronow WS. Prevalence of coexistence of coronary artery disease, ischemic stroke, and peripheral arterial disease in older persons, mean age 80 years, in an academic hospital based geriatrics practice. J Am Geriatr Soc. 1999;47(10):1255-6.

2. Hirsch AT, Haskal ZJ, Hertzer NR, Bakal CW, Creager MA, Halperin JL, et al. ACC/AHA 2005 Practice Guidelines for the management of patients with peripheral arterial disease (lower extremity, renal, mesenteric, and abdominal aortic): a collaborative report from the American Association for Vascular Surgery/Society for Vascular Surgery, Society for Cardiovascular Angiography and Interventions, Society for
Vascular Medicine and Biology, Society of Interventional Radiology, and the ACC/AHA Task Force on Practice Guidelines (Writing Committee to Develop Guidelines for the Management of Patients With Peripheral Arterial Disease): endorsed by the American Association of Cardiovascular and Pulmonary Rehabilitation; National Heart, Lung, and Blood Institute; Society for Vascular Nursing; TransAtlantic Inter-Society Consensus; and Vascular Disease Foundation. Circulation. 2006;113(11):e463-654.

3. Gibbons RJ, Abrams J, Chatterjee K, Daley J, Deedwania PC, Douglas JS, et al. ACC/AHA 2002 guideline update for the management of patients with chronic stable angina-summary article: a report of the American College of Cardiology/American Heart Association Task Force on practice guidelines (Committee on the Management of Patients With Chronic Stable Angina). J Am Coll Cardiol. 2003;41(1):159-68.

4. Mendis S, Lindholm LH, Mancia G, Whitworth J, Alderman M, Lim S, et al. World Health Organization (WHO) and International Society of Hypertension (ISH) risk prediction charts: assessment of cardiovascular risk for prevention and control of cardiovascular disease in low and middle-income countries. J Hypertens. 2007;25(8):1578-82.

5. Goldstein LB, Adams R, Alberts MJ, Appel LJ, Brass LM, Bushnell CD, et al. Primary prevention of ischemic stroke: a guideline from the American Heart Association/American Stroke Association Stroke Council: cosponsored by the Atherosclerotic Peripheral Vascular Disease Interdisciplinary Working Group; Cardiovascular Nursing Council; Clinica Cardiology Council; Nutrition, Physical Activity, and Metabolism Council; and the Quality of Care and Outcomes Research Interdisciplinary Working Group. Circulation. 2006;113(24):e873-923.

6. Preventive cardiology: how can we do better? Proceedings of the 33rd Bethesda Conference. Bethesda, Maryland, USA. December 18, 2001. J Am Coll Cardiol. 2002;40(4):580-651.

7. Smith SC Jr, Allen J, Blair SN, Bonow RO, Brass LM, Fonarow $\mathrm{GC}$, et al. AHA/ACC guidelines for secondary prevention for patients with coronary and other atherosclerotic vascular disease: 2006 update endorsed by the National Heart, Lung, and Blood Institute. J Am Coll Cardiol. 2006;47(10):2130-9.

8. Gaziano JJ, Ridker MP. Primary and secondary prevention of coronary heart disease. In: Zipes D, editor. Heart disease: a textbook of cardiovascular medicine. Philadelphia: Elsevier; 2005. p. 1057-84.

9. White C. Clinical practice: intermittent claudication. $\mathrm{N}$ Engl J Med. 2007;356(12):1241-50.

10. Norgren L, Hiatt WR, Dormandy JA, Nehler MR, Harris KA Fowkes FG; TASC II Working Group. Inter-society consensus for the management of peripheral arterial disease (TASC II). J Vasc Surg. 2007;45 Suppl S:S5-67.

11. Newman AB, Shemanski L, Manolio TA, Cushman M, Mittelmark M, Polak JF, et al. Ankle-arm index as a predictor of cardiovascular disease and mortality in the Cardiovascular Health Study. The Cardiovascular Health Study Group. Arterioscler Thromb Vasc Biol. 1999;19(3):538-45

12. Norman PE, Davis WA, Bruce DG, Davis TM. Peripheral arterial disease and risk of cardiac death in type 2 diabetes: the Fremantle Diabetes Study. Diabetes Care. 2006;29(3):575-80.

13. Papa ED, Helber I, Ehrlichmann MR, Alves CM, Makdisse M, Matos LN, et al. Ankle-brachial index as a predictor of coronary disease events in elderly patients submitted to coronary angiography. Clinics (São Paulo). 2013;68(12):1481-7.

14. Fowkes FG, Murray GD, Butcher I, Folsom AR, Hirsch AT, Couper DJ, et al. Development and validation of an ankle brachial index model for the prediction of cardiovascular events. Eur J Prev Cardiol. 2014;21(3):310-20. 
15. Lin JS, Olson CM, Johnson ES, Whitlock EP. The ankle-brachial index for peripheral artery disease screening and cardiovascular disease prediction among asymptomatic adults: a systematic evidence review for the U.S. Preventive Services Task Force. Ann Intern Med. 2013;159(5):333-41.

16. Whitfield MD, Gillett M, Holmes M, Ogden E. Predicting the impact of population level risk reduction in cardio-vascular disease and stroke on acute hospital admission rates over a 5 year period--a pilot study. Public Health. 2006;120(12):1140-8.

17. Aronow WS, Ahn C. Prevalence of coexistence of coronary artery disease, peripheral arterial disease, and atherothrombotic brain infarction in men and women $>$ or $=62$ years of age. Am J Cardiol. 1994;74(1):64-5.
18. McDermott MM, Greenland P, Liu K, Guralnik JM, Celic $\mathrm{L}$, Criqui $\mathrm{MH}$, et al. The ankle brachial index is associated with leg function and physical activity: the Walking and Leg Circulation Study. Ann Intern Med. 2002;136(12):873-83.

19. Lee AJ, Price JF, Russell MJ, Smith FB, van Wijk MC, Fowkes FG. Improved prediction of fatal myocardial infarction using the ankle brachial index in addition to conventional risk factors: the Edinburgh Artery Study. Circulation. 2004;110(19):3075-80.

20. Otah KE, Madan A, Otah E, Badero O, Clark LT, Salifu MO. Usefulness of an abnormal ankle-brachial index to predict presence of coronary artery disease in African-Americans. Am J Cardiol. 2004;93(4):481-3. 